\title{
Endocytotic Vesicle
}

National Cancer Institute

\section{Source}

National Cancer Institute. Endocytotic Vesicle. NCI Thesaurus. Code C32512.

A membrane-bound vesicle that is involved in transport of extracellular factors into a cell. 